\title{
Influence of the Addition of Urea-Formaldehyde Adhesive to Liquefied Wood on Curing
}

\section{Utjecaj dodatka urea-formaldehidnog ljepila u ukapljeno drvo na proces stvrdnjavanja}

\author{
Original scientific paper - Izvorni znanstveni rad \\ Received-prispjelo: 26. 7. 2012. \\ Accepted-prihvaćeno: 21. 6. 2013. \\ UDK: $630 * 824.328 ; 630 * 824.42$ \\ doi:10.5552/drind.2013.1239
}

\begin{abstract}
Urea-formaldehyde adhesive is one of the most frequently used types of amino resins for wood bonding. However, due to its synthetic origin, more environmentally friendly adhesives are desired. Liquefied wood is one of the natural-based alternatives. In this research, wood was liquefied using a procedure in which low solvent content liquefied wood was obtained. For the purpose of this study, urea-formaldehyde adhesive was added to the liquefied wood in proportions of 0, 10, 20, 30 and 40\%. Differential scanning calorimetry and rheological oscillatory test techniques were used to analyze the curing process and the hardening behavior of different adhesive mixtures. Additionally, wood lamellas were bonded with the same adhesive mixtures, and the shear strength of the bonds was evaluated. It was found that the addition of urea-formaldehyde adhesive to liquefied wood led to the occurrence of multiple chemical reactions during the curing process, and that the higher amount of ureaformaldehyde adhesive lowered the temperature at which gelation of the adhesive mixture occurred. It was also found that the adhesive mixtures with lower portions of urea-formaldehyde adhesive did not contribute to higher bond shear strengths compared to specimens bonded with pure liquefied wood, and that none of the specimens met the standard requirements for non-structural applications under dry conditions.
\end{abstract}

Key words: liquefied wood, urea-formaldehyde adhesive, differential scanning calorimetry, rheometry, shear strength

SAŽETAK • Urea-formaldehidno ljepilo jedna je od najčešće primjenjivanih aminosmola za lijepljenje drva. Međutim, zbog sintetičnog podrijetla tog ljepila, poželjnija su ekološki prihvatljivija ljepila. Ukapljeno drvo jedna je od alternativa na prirodnoj bazi. U ovom istraživanju drvo je ukapljeno primjenom postupka u kojemu se takvo drvo dobije uz mali sadržaj otapala. Za potrebe istraživanja, urea-formaldehidno ljepilo dodano je u ukapljeno drvo u omjerima od 0, 10, 20, 30 i $40 \%$. Diferencijalno skeniranje kalorimetrijom i reološko-oscilatorni ispitni postupak primijenjeni su za analizu procesa stvrdnjavanja i ponašanje različitih smjesa ljepila tijekom stvrdnjavanja. Osim toga, drvene su lamele slijepljene istim smjesama ljepila te je analizirana smicajna čvrstoća spoja. Utvrđeno je da je dodatak urea-formaldehidnog ljepila u ukapljeno drvo doveo do pojave višestruke kemijske reakcije tijekom procesa stvrdnjavanja te da je veća količina urea-formaldehidnog ljepila spustila temperaturu na kojoj počinje geliranje smjese ljepila. Također je utvrđeno da smjese ljepila s nižim udjelima urea-formaldehidnog

\footnotetext{
${ }^{1}$ Authors are research assistant and associate professor at Biotechnical Faculty, University of Ljubljana, Ljubljana, Slovenia. ${ }^{2}$ Author is project manager at a company M SORA d.d., Žiri, Slovenia.

${ }^{1}$ Autori su znanstveni asistent i izvanredni profesor Biotehničkog fakulteta Sveučilišta u Ljubljani, Ljubljana, Slovenija. ${ }^{2}$ Autor je voditelj projekata u tvrtki M SORA d.d. Žiri, Slovenija.
} 
ljepila nisu pridonijele većoj smicajnoj čvrstoći spoja u odnosu prema uzorcima slijepljenima čistim ukapljenim drvom te da nijedan od spojeva ispitivanih uzoraka nije pokazao svojstva koja odgovaraju standardnim zahtjevima za nestrukturne primjene u suhim uvjetima.

Ključne riječi: ukapljeno drvo, urea-formaldehidno ljepilo, diferencijalno skeniranje kalorimetrijom, reometrija, smicajna čvrstoća

\section{INTRODUCTION}

\section{UVOD}

Liquefied wood is a natural-based product obtained by a process that involves the liquefaction and transformation of solid wood material into the liquid state. Due to its liquid properties, ability to wet the wood surface and to solidify, liquefied wood is a convenient material to be used as an adhesive for wood bonding (Ugovšek and Šernek, 2013a; Ugovšek et al., 2013a). Various types of blends of synthetic adhesives and liquefied wood, as well as synthesized liquefied wood based polymers and even pure liquefied wood, have been studied and used for the purpose of wood bonding. So far, melamine-formaldehyde and melamine-urea-formaldehyde adhesives have been blended with liquefied wood for the production of particleboards and up to $50 \%$ of resin could be replaced by liquefied wood to produce the product in accordance with the requirements of the European Standard for particle boards (Kunaver et al., 2010; Čuk et al., 2011). Antonović et al. (2010) used different mixtures of urea-formaldehyde adhesive and liquefied wood with the same intention. Hassan et al. (2009) made a phenol-formaldehyde-type adhesive based on liquefied wood, and used it for the production of particleboards. Particleboards bonded with synthesized resins showed comparable results to particleboards bonded with ureaformaldehyde adhesive and the free formaldehyde emission was significantly lower. The synthesis of epoxy resins based on liquefied wood and the properties of such resins have been extensively studied (Kobayashi et al., 2000; Kishi et al., 2006; Wu and Lee, 2010; Kishi et al., 2011) and all epoxy-liquefied wood resins showed comparable properties to epoxy resins. However, the portion of wood in such resins was relatively low. Therefore, Asano et al. (2007) synthesized epoxy resin based on ozone-treated liquefied wood with a high wood content and obtained the properties comparable to the properties of already mentioned epoxy-liquefied wood resins. Alkali-catalyzed liquefied wood has been used for the preparation of adhesives for plywood (Maldas et al., 1997; Alma et al., 2001). The dry bond strength of plywood met the standard requirements, whereas the strength of plywood after the boiling was problematic. Wood has also been bonded with liquefied wood as an independent component. In such cases it was found that the shear strength of the bonded assemblies failed to meet the standard requirements for non-structural applications, and high wood failure was present (Ugovšek et al., 2011; Ugovšek and Šernek, 2013b). Such a phenomenon was ascribed to the degradation of the basic wood polymers in the wood cells where the liquefied wood had been applied. Consequently, a specific type of bond line containing a partly carbonized structure was present (Ugovšek et al., 2013b).

Understanding of hardening behavior and of the curing process of adhesives and adhesive mixtures is of great importance for their further applications, e.g. for wood bonding. Dynamic mechanical analysis is a very useful method that can be used to monitor the physical properties of polymers. With this method different modules and other physical properties of material are measured as a function of temperature. Rheometry is a similar technique, in which various rheological parameters (viscosity, storage and loss modulus) can be determined by means of a rheometer (Malkin and Kulichikhin, 1991). Based on these parameters, which depend on the curing temperature and time, the whole curing process (and, in particular, gelation and vitrification) can be determined (Winter, 2003; Mravljak and Šernek, 2011).

Differential scanning calorimetry is another useful technique for studying the physical transformations and chemical reactions of various materials during curing. This is one of the most widely used thermal analysis techniques for the study of polymeric materials (Menczel and Prime, 2009). Differential scanning calorimetry was used to study liquefied wood/phenol/formaldehyde resins (Pan et al., 2008) and polyurethane resins based on liquefied wood (Wei et al., 2004). The thermal behavior of liquefied wood polymer composites (Doh et al., 2005), the kinetics of a blend of liquefied wood and melamine-urea-formaldehyde (Poljanšek et al., 2013), and the curing process of pure liquefied wood (Ugovšek and Sernek, 2013a) was also studied using differential scanning calorimetry.

The aim of the research described in this paper was to elucidate the curing process and hardening behavior of different adhesive mixtures made of liquefied wood and urea-formaldehyde adhesive by means of differential scanning calorimetry, rheometry, and the bond shear strength test.

\section{MATERIALS AND METHODS}

\section{MATERIJALI I METODE}

\subsection{Preparation of liquefied wood}

2.1. Priprema ukapljenog drva

Wood was liquefied according to liquefaction procedure described by Ugovšek et al. (2011). Sawdust of the black poplar (Populus nigra L.) was used for the production of liquefied wood (LW). Prior to the liquefaction process, the sawdust was dried in a laboratory oven $\left(103{ }^{\circ} \mathrm{C}, 24 \mathrm{~h}\right)$. Black poplar wood and ethylene 
glycol (EG) as the solvent, in a mass ratio of 1:3, were used for liquefaction. $3 \%$ of sulphuric acid, based on the EG mass, was added as a catalyst. All liquefied wood was obtained by a single process. Liquefaction was carried out for a period of 120 minutes in a 1000 $\mathrm{mL}$ three-neck glass reactor, which was immersed in an oil bath that had been preheated to $180{ }^{\circ} \mathrm{C}$ and was equipped with a mechanical stirrer. After liquefaction, the reactor was immersed in cold water in order to quench the reaction. The liquefied product was then diluted with a mixture of 1,4-dioxane and water (4/1, $\mathrm{v} / \mathrm{v}$ ), and filtered through filter disks (Sartorius filter disks 388 grade $/ 84 / \mathrm{mm}^{2}$ ) in order to remove the insoluble parts of the LW and to determine the liquefaction yield, which was $94 \%$. In order to obtain the LW without the mixture of 1,4-dioxane and water, a rotary evaporator (Büchi, Rotavapor R-210) was used for evaporation at $55{ }^{\circ} \mathrm{C}$. Evaporation was performed at reduced pressure, from $100 \mathrm{kPa}$ to $1 \mathrm{kPa}$, which was achieved by means of a vacuum pump (Vacuubrand, PC 3003 Vario). After evaporation of the 1,4-dioxane, the EG in the $\mathrm{LW}$ was also evaporated (at $120^{\circ} \mathrm{C}, 1$ $\mathrm{kPa}$ ) so that a final wood/EG mass ratio of approximately 1:1 was achieved.

\subsection{Preparation of adhesive mixtures}

\subsection{Priprema smjesa ljepila}

Several adhesive mixtures were prepared as shown in Table 1. Mixing procedure was done using glass stick for $60 \mathrm{~s}$ and the percentage of components is based on the mass of components. Commercial ureaformaldehyde (UF) adhesive Lendur-200 was obtained from Nafta-petrochem, d.o.o. (Slovenia). No catalyst, extender or filler was used in the prepared adhesive mixtures.

Table 1 Adhesive mixtures prepared with a combination of LW and commercial UF adhesive

Tablica 1. Smjese ljepila pripremljene kombinacijom LW-a i komercijalnih UF ljepila

\begin{tabular}{|c|}
\hline $\begin{array}{c}\text { Adhesive mixtures } \\
\text { Smjese ljepila }\end{array}$ \\
\hline $100 \% \mathrm{LW}$ \\
\hline $90 \% \mathrm{LW}, 10 \% \mathrm{UF}$ \\
\hline $80 \% \mathrm{LW}, 20 \% \mathrm{UF}$ \\
\hline $70 \% \mathrm{LW}, 30 \% \mathrm{UF}$ \\
\hline $60 \% \mathrm{LW}, 40 \% \mathrm{UF}$ \\
\hline
\end{tabular}

LW - liquefied wood / ukapljeno drvo

UF - urea-formaldehyde adhesive / urea-formaldehidno ljepilo

\subsection{Differential scanning calorimetry (DSC)}

2.3. Diferencijalno skeniranje kalorimetrijom (DSC)

DSC measurements were performed in order to investigate the physical transformations and chemical reactions, which occurred during the curing of the adhesive mixtures. A high-pressure differential scanning calorimeter - HP DSC 1 (Mettler Toledo) with $30 \mu \mathrm{l}$ platinum crucibles was used for the curing of the adhe- sive mixtures within the temperature range from 30 to $350{ }^{\circ} \mathrm{C}$, with a heating rate of $10{ }^{\circ} \mathrm{C} / \mathrm{min}$. An empty crucible served as a reference. A dynamic nitrogen atmosphere with a flow rate of $50 \mathrm{ml} / \mathrm{min}$ at normal pressure ( 1 bar) was used. The masses of the adhesive mixture samples for the HP DSC measurements were between 6.64 and $7.53 \mathrm{mg}$.

\subsection{Rheological oscillatory test (RheOT) \\ 2.4. Reološki oscilatorni test (RheOT)}

Rheological measurements of the adhesive mixtures during curing were performed using a stress control rheometer ARES G2 (TA Instruments). Disposable aluminum plates with a diameter of $25 \mathrm{~mm}$ were used for the oscillation tests. A gap of $0.5 \mathrm{~mm}$ between the plates was used. All the RheOTs were performed at a frequency of $10 \mathrm{rad} / \mathrm{s}$, at a strain of $1.0 \%$, and at a heating rate of $10^{\circ} \mathrm{C} / \mathrm{min}$ within a temperature range of up to $225^{\circ} \mathrm{C}$. The intention was to achieve the same temperatures as those used in the DSC measurements (up to 350 ${ }^{\circ} \mathrm{C}$ ), but due to the high axial force that arose during the measurements, the transducer automatically turned off after its overload at temperatures higher than $225^{\circ} \mathrm{C}$.

\subsection{Bonding and testing of specimens}

2.5. Spajanje $\mathrm{i}$ ispitivanje slijepljenih uzoraka

Solid beech wood lamellas (Fagus sylvatica L.) with dimensions of $15 \times 15 \times 0.5 \mathrm{~cm}$ were used as a substrate for the preparation of two-layered test specimens, which were bonded according to EN 12765 by using a small laboratory conventional hot-press. Prior to bonding, all of the beech wood lamellas were planed in order to ensure smooth and flat surfaces. Two lamellas were then bonded together with different adhesive mixtures. Each of the adhesive mixtures was applied by means of a roller, using an application rate of $200 \mathrm{~g} /$ $\mathrm{m}^{2}$. The press temperature was $180{ }^{\circ} \mathrm{C}$, and the pressing time was 15 minutes. The specific pressure was 0.4 $\mathrm{MPa}$. The bonded specimens $(n=10)$ were tested after 7 days of conditioning in a standard climate $\left(20 \pm 2{ }^{\circ} \mathrm{C}\right.$, relative humidity $65 \pm 5 \%)$. All the shear tests were carried out on a ZWICK/Z005 universal testing machine according to the standard EN 205.

\section{RESULTS AND DISCUSSION 3. REZULTATI I RASPRAVA}

\subsection{DSC of adhesive mixtures during curing}

3.1. DSC tijekom stvrdnjavanja različitih smjesa ljepila

The physical transformations and chemical reactions, which occurred during the curing of different adhesive mixtures using LW and UF adhesive, were investigated by means of calorimetrical response (Figure 1). The curing of pure LW (solid line) is divided into two phases. Evaporation of water can be observed as an initial broad and shallow endothermic signal, which is followed by another more prominent endothermic signal representing evaporation of the EG. At around $180^{\circ} \mathrm{C}$, the chemical curing of LW began, indicated by a broad exothermic signal with its maximum 


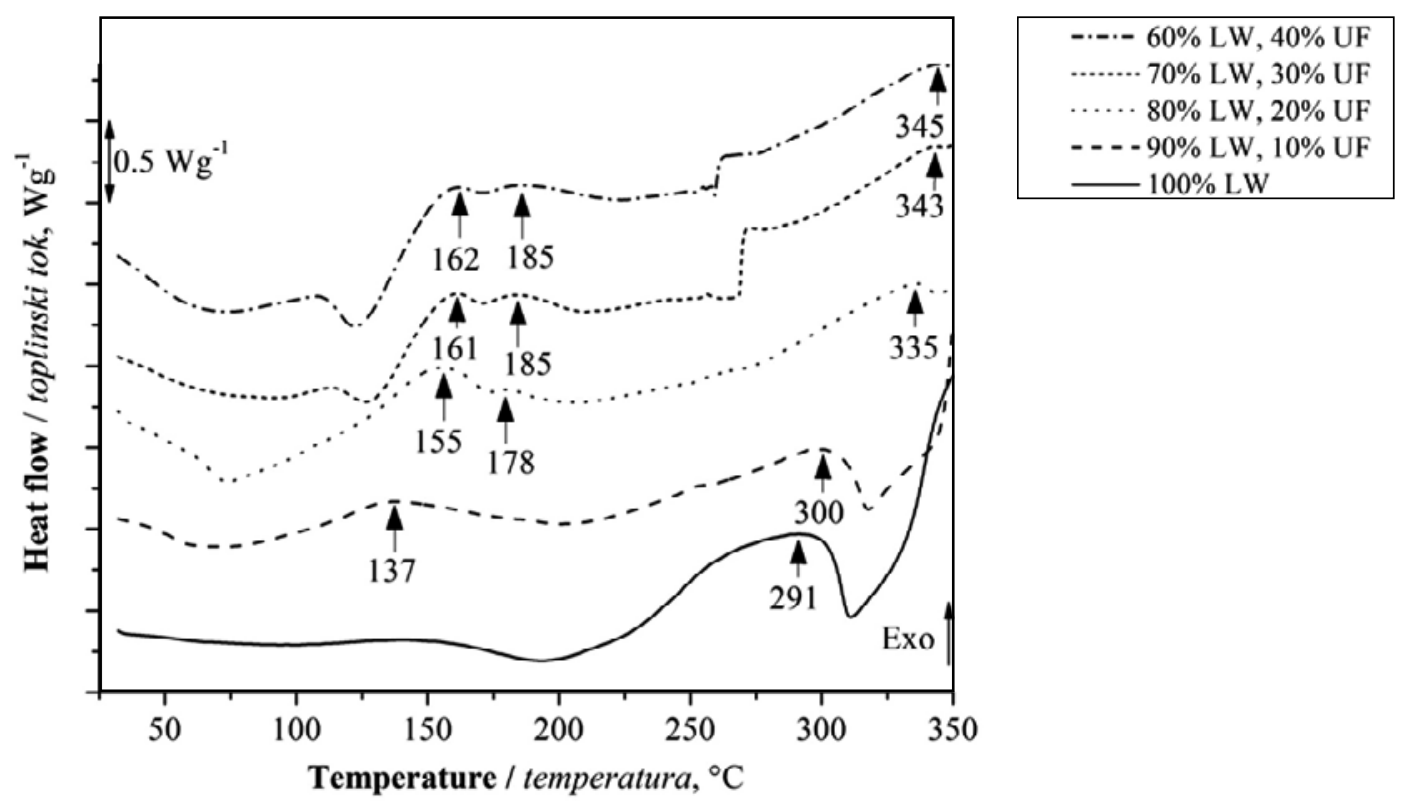

Figure 1 DSC thermograms - the curing process of different adhesive mixtures within a temperature range from 30 to 350 ${ }^{\circ} \mathrm{C}$ and at a heating rate of $10^{\circ} \mathrm{C} / \mathrm{min}$

Slika 1. DSC termogrami - proces stvrdnjavanja različitih smjesa ljepila u intervalu temperature od 30 do $350{ }^{\circ} \mathrm{C}$ i pri brzini zagrijavanja od $10^{\circ} \mathrm{C} / \mathrm{min}$

point at $291{ }^{\circ} \mathrm{C}$ (Ugovšek and Šernek, 2013a). The 10 $\%$ addition of UF adhesive to the $\mathrm{LW}$ was reflected in a shift of the exothermic signal related to the LW to a slightly higher temperature $\left(300^{\circ} \mathrm{C}\right)$, but a new exothermic signal was observed at $137^{\circ} \mathrm{C}$. This signal is related to the curing reaction of the UF adhesive, which was induced by the LW and its low $\mathrm{pH}$ value (Ugovšek and Šernek, 2013b). Additionally this might mean that the UF resin and LW were not completely miscible. It was observed that the increasing of UF portion in the adhesive mixture was reflected in a shift of the LW exothermic signal to even higher temperatures $\left(335^{\circ} \mathrm{C}\right.$, $343^{\circ} \mathrm{C}$ and $345^{\circ} \mathrm{C}$ ), and also in a shift of the UF exothermic signal up to $162^{\circ} \mathrm{C}$. The reason for such high temperatures related to UF curing is that no catalyst, which is normally added when bonding wood with UF adhesive, was present in the prepared adhesive mixtures. Besides this, a new exothermic signal was observed at $178{ }^{\circ} \mathrm{C}(80 \% \mathrm{LW}, 20 \% \mathrm{UF})$ and at $185{ }^{\circ} \mathrm{C}$ (70\% LW, 30\% UF and 60\% LW, 40\% UF), which indicated the presence of multiple chemical reactions during the curing of the LW-UF adhesive mixture.

\subsection{Rheological response of LW during curing \\ 3.2. Reološki odgovor ukapljenog drva tijekom stvrdnjavanja}

RheOTs were used to obtain a curing profile of the adhesive mixtures by means of their rheological response to an oscillating load generated by the instrument. The curing of the investigated material can be monitored by means of two different parameters: the storage modulus $\left(G^{\prime}\right)$ and the loss modulus $\left(G^{\prime \prime}\right) . G^{\prime}$ represents the elastic behavior and is a measure of the deformation energy stored in the sample during the shear process, whereas $G^{\prime \prime}$ represents the viscous behavior of the sample and is a measure of the deformation energy used in the sample during the shearing process and afterwards lost to the sample (Mezger, 2002). The ratio between these two modules is called the loss tangent $(\tan \delta)$, and it can be used to define the gel point. The latter occurs at the point where $G^{\prime}$ crosses $G^{\prime \prime}$ and where $\tan \delta$ equals 1 . At this point, $\tan \delta$ should be independent of the applied frequency (Winter, 1987). Núnez et al. (2005) found that gel times calculated from the single-frequency experiment are in close relation with results obtained from multiple frequency experiments. Another useful parameter for describing hardening behavior of the adhesive mixtures is complex viscosity $\left(\eta^{*}\right) . \eta^{*}$ is the vectorial sum of the elastic and loss component of the dynamic viscosity, and a measure of the general resistance of a material to flow as a function of the stress rate (Garnier et al., 2002). According to Malkin and Kulichikhin (1991), viscosity starts to increase near the gel point. $\eta^{*}$ as a function of temperature was used for the interpretation of the hardening behavior of the adhesive mixtures (Figure 2), and the temperature of the gel points (gelation temperatures) based on the intersection of $G^{\prime}$ and $G^{\prime \prime}$ were also compared (Table 2).

Two visible changes occurred due to the addition of UF to LW (Figure 2). First, the value of $\eta^{*}$ at $50{ }^{\circ} \mathrm{C}$ was higher when there was an increased amount of UF adhesive in the adhesive mixture. Furthermore, in the case of UF additions of $30 \%$ and $40 \%$, the gel time was so short that some gelling was already present by the time the sample had been placed and the measurement started. A second visible change among the adhesive mixtures was the temperature at which an increase of $\eta$ * began. It is clear that the increased addition of UF adhesive to LW accelerated the curing reaction and simultaneously decreased the starting temperature of curing, which is not in relation to DSC results. The reason 


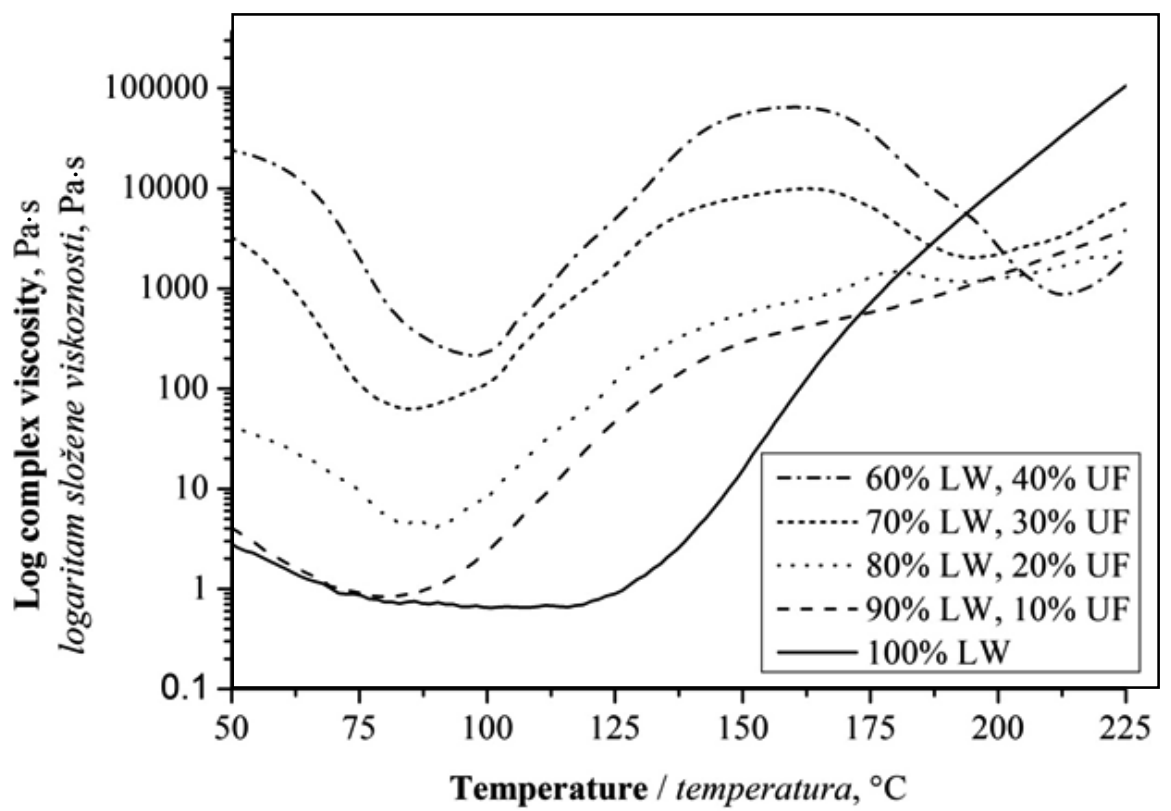

Figure 2 Hardening behavior (change of complex viscosity) of different adhesive mixtures

Slika 2. Ponašanje tijekom stvrdnjavanja (promjena složene viskoznosti) različitih smjesa ljepila

for this is the nature of the two techniques: chemical changes are measured with DSC, whereas the physical aspect is obtained with rheometry. In rheological test, a very important factor is the loss of moisture, which is correlated to the gelation of the specific resin. However, the most noticeable changes occurred between the adhesive mixtures without and with $10 \%$ and $20 \%$ of UF adhesive. The changes between the adhesive mixtures with $30 \%$ and $40 \%$ were not so significant. In the latter two cases a decrease was observed in the value of $\eta^{*}$ after the temperature of about $170^{\circ} \mathrm{C}$ had been reached, which is correlated with the cracking of molecular bonds in the sample due to oscillatory loading.

The temperature of the gel point (gelation temperature) was calculated from the crossing point of $G^{\prime}$ and $G^{\prime \prime}$ i.e. the $\tan \delta$ value of 1 (Table 2 ).

Table 2 Influence of the addition of different amounts of UF adhesive to LW on gelation temperature

Tablica 2. Utjecaj dodatka različitih količina UF ljepila u ukapljeno drvo na temperaturu geliranja

\begin{tabular}{|c|c|}
\hline $\begin{array}{c}\text { Adhesive mixture } \\
\text { Smjesa ljepila }\end{array}$ & $\begin{array}{c}\text { Gelation temperature, }{ }^{\circ} \mathrm{C} \\
\text { Temperatura geliranja, }{ }^{\circ} \mathrm{C}\end{array}$ \\
\hline $100 \% \mathrm{LW}$ & 141 \\
\hline $90 \% \mathrm{LW}, 10 \% \mathrm{UF}$ & 124 \\
\hline $80 \% \mathrm{LW}, 20 \% \mathrm{UF}$ & 113 \\
\hline $70 \% \mathrm{LW}, 30 \% \mathrm{UF}$ & 96 \\
\hline $60 \% \mathrm{LW}, 40 \% \mathrm{UF}$ & 91 \\
\hline
\end{tabular}

LW - liquefied wood / ukapljeno drvo

UF - urea-formaldehyde adhesive / urea-formaldehidno ljepilo

It is clear that the addition of UF adhesive decreased the temperature of the gelation temperature. These results are in correlation with the $\eta^{*}$ results. Even a small amount of UF adhesive decreased the gelation temperature by more than $15^{\circ} \mathrm{C}$, whereas a $40 \%$ addi- tion of UF adhesive to the LW decreased gelation temperature by $50{ }^{\circ} \mathrm{C}$.

\subsection{Shear strength of specimens bonded with different adhesive mixtures}

3.3. Smicajna čvrstoća uzoraka slijepljenih različitim smjesama ljepila

Beech wood lamellas were bonded with pure LW and the prepared adhesive mixtures with a combination of LW and UF adhesive. The results of the shear strength tests revealed that a $10 \%$ and $20 \%$ addition of UF adhesive to the LW did not improve the shear strength of the bonded specimens (Table 3). Adhesive

Table 3 Influence of different additions of UF adhesive to LW on shear strength and wood failure of bonded specimens (standard deviation is shown in parenthesis; adhesive mixtures marked with asterisk could not be used for bonding due to rapid gelation and inability to be applied to the wood surface)

Tablica 3. Utjecaj dodatka različitih količina UF ljepila u ukapljeno drvo na smicajnu čvrstoću i lom po drvu slijepljenih uzoraka (standardna devijacija dana je u zagradi; smjese ljepila označene zvjezdicom ne mogu se primjenjivati za lijepljenje zbog brzog stvrdnjavanja i nemogućnosti primjene na drvnim površinama)

\begin{tabular}{|c|c|c|}
\hline $\begin{array}{c}\text { Adhesive } \\
\text { mixture } \\
\text { Smjesa ljepila }\end{array}$ & $\begin{array}{c}\text { Shear strength } \\
\text { Smicajna } \\
\text { čvrstoća } \mathrm{N} / \mathrm{mm}^{2}\end{array}$ & $\begin{array}{c}\text { Wood failure } \\
\text { Lom po drvu } \\
\%\end{array}$ \\
\hline $100 \% \mathrm{LW}$ & $7.4(1.1)$ & $100(0)$ \\
\hline $\begin{array}{c}90 \% \mathrm{LW}, 10 \% \\
\mathrm{UF}\end{array}$ & $7.1(1.0)$ & $88(27)$ \\
\hline $\begin{array}{c}80 \% \mathrm{LW}, 20 \% \\
\mathrm{UF}\end{array}$ & $7.1(1.8)$ & $0(32)$ \\
\hline $\begin{array}{c}70 \% \mathrm{LW}, 30 \% \\
\mathrm{UF} *\end{array}$ & $0(0)$ & $0(0)$ \\
\hline $\begin{array}{c}60 \% \mathrm{LW}, 40 \% \\
\mathrm{UF} *\end{array}$ & $0(0)$ & $0)$ \\
\hline
\end{tabular}


mixtures with a $30 \%$ and $40 \%$ addition of UF adhesive to the LW were not suitable for bonding due to the rapid gelation, as well as their high viscosity and inability to be applied by a roller.

The specimens bonded with pure LW achieved a shear strength of $7.4 \mathrm{~N} / \mathrm{mm}^{2}$, whereas the specimens bonded with adhesive mixtures containing $10 \%$ and 20 \% of UF adhesive achieved a shear strength of $7.1 \mathrm{~N} /$ $\mathrm{mm}^{2}$. However, the shear strength values did not show any significant differences between these adhesive mixtures, although attention needs to be paid to wood failure. Wood failure was very high in the case of pure LW. This has already been reported by Ugovšek et al. (2011), and is correlated to the low $\mathrm{pH}$ value of the LW and damage to the bonded surface (Ugovšek and Šernek, 2013b; Ugovšek et al., 2013b). With the addition of UF adhesive, wood failure decreased due to the lower acidity of the adhesive mixture, and was also aggravated by the spreading and penetration of the adhesive mixtures due to increased viscosity correlated to gelling. Nevertheless, bond shear strength remained too low to meet the standard requirements $\left(10 \mathrm{~N} / \mathrm{mm}^{2}\right)$.

\section{CONCLUSIONS}

\section{ZAKLJUČAK}

Commercial urea-formaldehyde adhesive was added to low solvent liquefied wood, and the curing process and hardening behavior of adhesive mixtures with different proportions between these two components was evaluated using differential scanning calorimetry and rheological oscillatory tests. Shear strength tests of specimens bonded with different adhesive mixtures were also performed.

Differential scanning calorimetry showed a single exothermic signal that was correlated to the chemical reaction that occurred during the curing of pure liquefied wood, after evaporation of water and ethylene glycol at around $290{ }^{\circ} \mathrm{C}$. A $10 \%$ addition of urea-formaldehyde adhesive resulted in an additional exothermic signal at lower temperatures, whereas the addition of higher amounts of adhesive led to even more exothermic signals, indicating multiple chemical reactions. The results of rheological oscillatory tests showed that the addition of urea-formaldehyde adhesive accelerated the curing of the adhesive mixtures, since the temperature at which the gel point occurred was lower in the case of a higher proportion of synthetic adhesive. The specimens bonded with adhesive mixtures with a $10 \%$ and $20 \%$ addition of urea-formaldehyde adhesive to the liquefied wood achieved similar bond strengths to those of specimens bonded with pure liquefied wood, but all of them failed to meet the standard requirements for non-structural applications under dry conditions.

\section{Acknowledgements - Zahvale}

The authors acknowledge the financial support of the Slovenian Research Agency through the Project J42177, Research Program P4-0015, and are grateful to Mr. Jure Žigon for technical support.

\section{REFERENCES}

\section{LITERATURA}

1. Alma, M. H.; Bastürk M. A.; Shiraishi N., 2001: Cocondensation of $\mathrm{NaOH}$-catalyzed liquefied wood wastes, phenol, and formaldehyde for the production of resoltype adhesives. Ind. Eng. Chem. Res. 40: 5036-5039. http://dx.doi.org/10.1021/ie000858x

2. Antonović, A.; Jambreković, B.; Kljak, J.; Španić, N.; Medved S., 2010: Influence of urea-formaldehyde resin modification with liquefied wood on particleboard properties. Drv. Ind. 61(1):5-14.

3. Asano, T.; Kobayashi, M.; Tomita, B.; Kajiyama, M., 2007: Syntheses and properties of liquefied products of ozone treated wood/epoxy resins having high wood contents. Holzforschung. 61: 14-18. http://dx.doi.org/10.1515/HE.2007.003

4. Čuk, N.; Kunaver, M.; Medved, S., 2011: Properties of particleboards made by using an adhesive with added liquefied wood. Materiali in tehnologije. 45: 241-245.

5. Doh, G.; Lee, S.; Kang, I.; Kong, Y., 2005: Thermal behavior of liquefied wood polymer composites (LWPC). Compos. Struct. 68: 103-108. http://dx.doi.org/10.1016/j.compstruct.2004.03.004

6. Garnier, S.; Pizzi, A.; Vorster, O.C.; Halasz, L., 2002: Rheology of polyflavonoid tannin-formaldehyde reactions before and after gelling. I. Methods J. Appl. Polym. Sci. 86: 852-863. http://dx.doi.org/10.1002/app.10991

7. Hassan, El B.; Kim, M.; Wan, H., 2009: Phenol-Formaldehyde-Type Resins Made from Phenol-Liquefied Wood for the Bonding of Particleboard J. Appl. Polym. Sci. 112: 1436-1443. http://dx.doi.org/10.1002/app.29521

8. Kishi, H.; Akamatsu, Y.; Noguchi, M.; Fujita, A.; Matsuda, S.; Nishida, H., 2011: Synthesis of Epoxy Resins from Alcohol-liquefied wood and the Mechanical Properties of the Cured Resins. J. Appl. Polym. Sci. 120: 745751. http://dx.doi.org/10.1002/app.33199

9. Kishi, H.; Fujita, A.; Miyazaki, H.; Matsuda, S.; Murakami, A., 2006: Synthesis of wood-based epoxy resins and their mechanical and adhesive properties. J. Appl. Polym. Sci. 102: 2285-2292.http://dx.doi.org/10.1002/app.24433

10. Kobayashi, M.; Tukamoto, K.; Tomita, B., 2000: Application of liquefied wood to a new resin system-synthesis and properties of liquefied wood/epoxy resins. Holzforschung. 54: 93-97. http://dx.doi.org/10.1515/HF.2000.014

11. Kunaver, M.; Medved, S.; Čuk, N.; Jasiukaityte, E.; Poljanšek, I.; Strnad, T., 2010: Application of liquefied wood as a new particle board adhesive system. Biores. Technol. 101: 1361-1368. http://dx.doi.org/10.1016/j.biortech.2009.09.066

12. Maldas, D.; Shiraishi, N.; Harada, Y., 1997: Phenolic resol resin adhesives prepared from alkali-catalyzed liquefied phenolated wood and used to bond hardwood. J. Adhes. Sci. Technol. 11(3): 305-316. http://dx.doi.org/10.1163/156856197X00714

13. Malkin, A.Y.; Kulichikhin, S.G., 1991: Rheokinetics of curing. Adv. Polym. Sci. 101: 217-257. http://dx.doi.org/10.1007/BFb0018003

14. Menczel, J.D.; Prime, R.B., 2009: Thermal analysis of polymers, Fundamentals and applications. John Wiley \& Sons, Hoboken, New Jersey. http://dx.doi.org/10.1002/9780470423837.index

15. Mezger, T.G., 2002: The rheology handbook. Vinzent Verlag, Hannover

16. Mravljak, M.; Šernek, M., 2011: The influence of curing temperature on rheological properties of epoxy adhe- 
sives. Drv. Ind. 62(1): 19-25.

http://dx.doi.org/10.5552/drind.2011.1042

17. Núñez-Regueira, L.; Gracia-Fernández, C.A.; GómezBarreiro, S., 2005: Use of rheology, dielectric analysis and differential scanning calorimetry for gel time determination of a thermoset. Polymer. 46: 5979-5985. http://dx.doi.org/10.1016/j.polymer.2005.05.060

18. Pan, H.; Shupe, T. F.; Hse; C. Y., 2008: Synthesis and cure kinetics of liquefied wood/phenol/formaldehyde resin. J. Appl. Polym. Sci. 108: 1837-1844. http://dx.doi.org/10.1002/app.27756

19. Poljanšek, I.; Likozar, B.; Čuk, N.; Kunaver. M., 2013: Curing kinetics study of melamine-urea-formaldehyde resin/liquefied wood, Wood Sci. Technol. 47(2): 395409. http://dx.doi.org/10.1007/s00226-012-0503-x

20. Ugovšek, A.; Budija, F.; Kariž, M.; Sernek, M., 2011: The influence of solvent content in liquefied wood and of the addition of condensed tannin on bonding quality. Drv. Ind. 62(2): 87-95. http://dx.doi.org/10.5552/drind.2011.1039

21. Ugovšek, A.; Sernek, M. 2013a: Characterisation of the curing of liquefied wood by rheometry, DEA and DSC. Wood Sci. Technol. 47: 1099-1111. http://dx.doi.org/10.1007/s00226-013-0565-4.

22. Ugovšek, A.; Sernek, M. 2013b: Effect of pressing parameters on the shear strength of beech specimens bonded with low solvent liquefied wood. J. Adhes. Sci. Technol. 27(2): 182-195. http://dx.doi.org/10.1080/01694243.2012.701529

23. Ugovšek, A.; Kamke, F.A.; Sernek, M.; Pavlič, M.; Kutnar, A. 2013a: The wettability and bonding performance of densified VTC beech (Fagus sylvatica L.) and Norway spruce (Picea abies (L.) Karst.) bonded with phenol-formaldehyde adhesive and liquefied wood. Eur. J. Wood Wood Prod., 71(3): 371-379. http://dx.doi.org/10.1007/s00107-013-0669-4

24. Ugovšek A, Sever Škapin A, Humar M, Sernek M 2013b: Microscopic analysis of the wood bond line using lique- fied wood as adhesive. J. Adhes. Sci. Technol. 27(11): 1247-1258. http://dx.doi.org/10.1080/01694243.2012.736854.

25. Wei, Y.; Cheng, F.; Li, H.; Yu, J., 2004: Synthesis and properties of polyurethane resins based on liquefied wood. J. Appl. Polym. Sci. 92: 351-356. http://dx.doi.org/10.1002/app.20023

26. Winter, H. H. 1987: Can the gel point of a cross-linking polymer be detected by the $\mathrm{G}^{\prime}$ - $\mathrm{G}^{\prime \prime}$ crossover?. Polym. Eng. Sci. 27: 1698-1702. http://dx.doi.org/10.1002/pen.760272209

27. Winter, H.H., 2003: Physical and chemical gelation. In: K.H.J. Buschow, R. Cahn, M. Flemings, B. Ilschner, E. Kramer, S. Mahajan, P. Veyssiere (ed): Encyclopedia of materials: Science and technology, Elsevier Ltd., pp 6991-6999. http://dx.doi.org/10.1016/B0-08-043152-6/01239-0

28. Wu, C.; Lee, W., 2010: Curing behavior and adhesion properties of epoxy resin blended with polyhydric alcohol-liquefied Cryptomeria japonica wood. Wood Sci. Technol. 45: 559-571. http://dx.doi.org/10.1007/s00226-010-0358-y

29. *** EN 12765: 2002: Classification of thermosetting wood adhesives for non-structural applications: 9pp.

30. *** EN 205: 2003: Adhesives - Wood adhesives for nonstructural applications - Determination of tensile shear strength of lap joints: 13pp.

\section{Corresponding address:}

\section{ALEŠ UGOVŠEK}

\section{SORA d.d.}

Trg svobode 2

SI-4226 Žiri, SLOVENIA

e-mail: ales.ugovsek@gmail.com 